\title{
E-Learning and Smart Revision Portal for Zambian Primary and Secondary School Learners: A Digitalized Virtual Classroom in the COVID-19 Era and Beyond
}

\author{
Edgar John Sintema ${ }^{1 *}$
}

${ }^{1}$ Institute of Virtual and Distance Learning (IVDL), DMI St. Eugene University, Chipata Campus, ZAMBIA

*Corresponding Author: edgarsintema1@gmail.com

Citation: Sintema, E. J. (2020). E-Learning and Smart Revision Portal for Zambian Primary and Secondary School Learners: A Digitalized Virtual Classroom in the COVID-19 Era and Beyond. Aquademia, 4(2), ep20017. https://doi.org/10.29333/aquademia/8253

ARTICLE INFO

Received: 25 Apr. 2020

Accepted: 3 May. 2020

\begin{abstract}
The emergence of coronavirus (COVID-19) and its rapid spread across Asia, Europe, United States of America and parts of Africa led to many republics implementing partial and complete lockdowns of their countries as part of the many solutions to curbing the pandemic. Internal measures included closure of all learning institutions and restricted mobility of citizens. Zambia responded by closure of schools and institutions of higher learning, and a partial lockdown. As an alternative to on-campus learning, some higher learning institutions in Zambia introduced E-learning for their students. This was not the case for primary and secondary schools until midAprils 2020 when educational responses started being implemented. This paper highlights the E-learning and smart revision facility, a virtual classroom for Zambian primary and secondary schools.
\end{abstract}

Keywords: e-learning and smart revision, virtual classroom, COVID-19 era
The coronavirus (COVID-19) outbreak and rapid spread came as a shock to countries around the world, infecting and killing thousands of people around the globe which led to the World Health Organization (WHO) to declare it a pandemic (World Health Organization, 2020b). Many countries around the world consider the COVID-19 pandemic a national Health disaster owing to its devastating effects on the economic and social sectors.

The education sector is one of the largest and most delicate social sectors that has been adversely affected by COVID-19 in Zambia and other countries around the world causing schools, colleges and universities to close indefinitely (Mulenga \& Marban, 2020, Naciri et al., 2020; Sintema, 2020) This led to alternative modes of learning and instruction in many universities around the world. In Zambia, universities introduced e-learning platforms (Mulenga \& Marban, 2020) to enable their students have continued access to lectures and assessment. With regards to primary and secondary school education, COVID-19 effects provided both opportunities and challenges (Toquero, 2020; Usak, 2020; Yan, 2020) for the Zambian Ministry of General Education. Challenges included inability for students to access the school and their teachers for academic consultation because of the self-isolation and social distancing practices. Amidst such challenges, COVID-19 presented opportunities for government to turn to other innovative alternatives of continuing the education of students away from schools. Research has indicated that COVID-19 could be seen as a gateway to digital learning that would include the use of social media platforms like Facebook and WhatsApp which are the most used platforms in Zambia by thousands of young people (Mulenga \& Marban, 2020).

The immediate response saw the introduction and launch of a Television education channel dedicated to airing educational content in form of lessons in various subject areas (Sintema, 2020). While this was viewed as a progressive innovation, long hours of load shading affected children's access to lessons which were being televised. To complement the educational programming on national Television and to increase access to education in the COVID-19 era and beyond, the Ministry of General Education launched the e-Learning and smart revision portal for Zambian primary and secondary school leaners. This is a digitalized virtual classroom where students can access lessons using mobile phones and other internet devices (Ministry of Education, 2020).

With the increasing need for learning institutions like schools to incorporate inovative methods of instruction (Toquero, 2020), transition to E-learning has emerged as an unavoidable option in the current COVID-19 era and beyond.(Bao, 2020; Basilaia, 2020; Naciri et al., 2020). Thus, introduction of the E-learning and smart revision portal will increase opportunities for the use of mobile devices like smart phones and tablets in accessing lessons. Mobile devices have 
been viewed to have advantages in helping students and teachers engage in teaching and self-regulated learning (AlEmran, 2016; Sha et al., 2012; Steel, 2012)

It has been observed through various educational studies that amidst challenges caused by coronavirus to the education sector lies numerous opportunities for innovative approaches to instruction that can be adopted by schools across the world because school children are usually, by far, the most vulnerable when it comes to use of technology in education. This is because E-learning is usually focused on higher education students leaving out thousands of primary and secondary school students.

\section{REFERENCES}

Al-Emran, M., Elsherif, H. M., \& Shaalan, K. (2016). Investigating attitudes towards the use of mobile learning in higher education. Computers in Human behavior, 56, 93102. https://doi.org/10.1016/j.chb.2015.11.033

Bao, W. (2020). COVID-19 and online teaching in higher education: A case study of Peking University. Human Behavior and Emerging Technologies. https://doi.org/ 10.1002/hbe2.191

Basilaia, G., \& Kvavadze, D. (2020). Transition to Online Education in Schools during a SARS-CoV-2 Coronavirus (COVID-19) Pandemic in Georgia. Pedagogical Research, 5(4). Em0060, http://10.29333/pr/7937

Ministry of General Education (2020). National E-learning and smart revision portal. Retrieved on 3 May 2020 from http://www..znbc.co.zm/news/e-learning

Mulenga, E. M., \& Marbán, J. M. (2020). Is COVID-19 the Gateway for Digital Learning in Mathematics Education?. Contemporary Educational Technology, 12(2), ep269. https://doi.org/10.30935/cedtech/7949
Naciri, A., Baba, M. A., Achbani, A., \& Kharbach, A. (2020). Mobile learning in Higher education: Unavoidable alternative during COVID-19. Aquademia, 4(1), ep20016. https://doi.org/10.29333/aquademia/8227

Sha, L., Looi, C. K., Chen, W., \& Zhang, B. H. (2012). Understanding mobile learning from the perspective of self-regulated learning. Journal of Computer Assisted Learning, 28(4), 366-378. https://doi.org/10.1111/j.13652729.2011.00461.x

Sintema, E. J. (2020). Effect of COVID-19 on the Performance of Grade 12 Students: Implications for STEM Education. Eurasia Journal of Mathematics, Science and Technology Education, 16(7), em1851. https://doi.org/10.29333/ejmste/ 7893

Steel, C. (2012, November). Fitting learning into life: Language students' perspectives on benefits of using mobile apps. In ascilite (pp. 875-880).

Toquero, C. M. (2020). Challenges and Opportunities for Higher Education amid the COVID-19 Pandemic: The Philippine Context. Pedagogical Research, 5(4), em0063. https://doi.org/10.29333/pr/7947

Usak, M., Masalimova, A. R., Cherdymova, E. I., \& Shaidullina, A. R. (2020). New playmaker in science education: Covid-19. Journal of Baltic Science Education, 19(2), 180185. https://doi.org/10.33225/jbse/20.19.180

World Health Organization. (2020b). Statement on the second meeting of the International Health Regulations (2005) Emergency Committee regarding the outbreak of novel coronavirus (2019-nCoV).

Yan, Z. (2020). Unprecedented pandemic, unprecedented shift, and unprecedented opportunity. Human Behavior and Emerging Technologies. https://doi.org/10.1002/hbe2.192 